\title{
Př́spěvek k problematice technologie výroby keramických nádob a její nomenklatury
}

\section{On the problem of production technology of ceramic vessels and its nomenclature}

\section{Lenka Běhounková}

\begin{abstract}
Abstrakt
Technologie výroby keramických nádob je náročný proces, který zahrnuje specifické postupy od těžby a př́pravy surovin, přes výrobu až k sušení a výpalu. Př́spěvek je věnován bližšímu poznání primárních výrobních technik a stop, které za sebou zanechávají na keramických nádobách. Větši pozornost je věnována zejména technikám, o jejichž používání lze uvažovat v různých historických obdobích od pravěku po vrcholný středověk. Jsou zde shrnuty poznatky nejen z archeologie, ale také z etnologie, experimentální archeologie a současného hrnčířství. Jedním z řešených témat je také otázka nejednotné terminologie a nesprávného užívání některých odborných termínů.
\end{abstract}

\section{Klíčová slova}

keramika, technologie výroby, identifikace výrobních technik, pravěk a středověk

\begin{abstract}
The production technology of ceramic vessels is a demanding procedure which includes specific phases and methods, from acquisition and preparation of raw materials, over production through to drying and firing. The paper is dealing in more detail with basic production techniques and specific traces which they leave on ceramic vessels. Special attention is mainly paid to techniques typical of various historical periods, from Prehistory to High Middle Ages. The text summarizes the knowledge not only of archaeology but also of ethnology, experimental archaeology and contemporary pottery making. Among the topics addressed also are the non-uniform terminology and incorrect use of several specialised terms.
\end{abstract}

\section{Keywords}

pottery, production technology, identification of production techniques, Prehistory and Middle Ages 


\section{1. Úvod}

Keramická technologie zahrnuje několik procesů, od přípravy keramických směsí, přes výrobu nádob, sušení, zdobení až po samotný výpal. $\mathrm{V}$ české archeologii nebyla tomuto tématu věnována př́lišná pozornost a studium technologie keramiky je zatíženo řadou stereotypů. Podrobnější práce zabývající se výrobou keramiky jsou zaměřeny především na technologie výpalu (Thér 2004; Thér 2009; Thér - Gregor 2011; Kovárnik 1982, 1983-84, 2005; Dvorská 2001; Bareš - Lička - Růžičková 1981, 1982; Tichý - Tintěra 2001; Tintèra - Červinková - Červinka 1986). Informace o způsobu výroby nádob se v odborné archeologické literatuře často omezují na konstatování, že nádoba byla vyrobena válečkovou technikou, obtočena či vytočena na kruhu (např. Pavli̊ 1971, 39; Reichertová 1965, 17; Podborský 2005, Vařeka, 1998). Tato zjištění se pak stávají součástí deskriptivních systémů, na jejichž základech je zpracovávána velká část archeologického materiálu (např. Procházka 2007, 241; Macháček 2001, 22; Vařeka 1998). Jakožto nedílná součást výsledných keramických nádob by se však technologie výroby měla stát důležitým kritériem při hodnocení keramiky. Podrobnější studium výrobních technologií rovněž může přinášet zajímavá zjištění nejen o technologiích samotných, ale také o otázkách specializace výroby a dalších socioekonomických aspektech života minulých populací ( $M a$ cháček 2001, 22; Thér 2009, 12-13, Shepard 1965, 183). Odlišná situace panuje zejména v zemích západní Evropy, kde jsou studiu technologie výroby nádob věnovány práce nejen etnologické (např. Virot 2005; Schneider 1991; Livingstone Smith 2010; Rye 1981; Rzeznik 1993, 1995; Buko 1990), ale také archeologické. Na vysoké úrovni je studium výrobních technik zejména ve Francii (Courty - Roux 1995; Dupont-Delaleuf 2011; Roux 2009; Roux - Corbetta 1989, Roux - Courty 1998).
Cílem tohoto příspěvku je poskytnout pohled na výrobní techniky nejen z pohledu archeologie nebo etnologie, ale také z pohledu samotného hrnčíŕství (pozn. autorka je absolventem Střední školy uměleckoprůmyslové a technické ve Velkých Opatovicích se zaměřením na uměleckořemeslné zpracování keramiky). Jsou v něm shrnuty základní archeologické i etnologické informace o výrobních technikách a stopách, které po sobě jednotlivé techniky mohou zanechávat na povrchu keramických nádob. Část příspěvku rovněž poukazuje na nejednotné používání některých odborných pojmů v archeologické literatuře a jeho snahou je proto také ucelení nomenklatury týkající výrobních technik a s nimi souvisejících dalších pojmů.

\section{Terminologie a príklady užívání některých pojmů}

Velkým problémem při studiu výrobních technik a obecně i při zpracování jakéhokoli keramického souboru je neexistující ucelená a jednoznačná terminologie. Nejen v české archeologii se setkáváme s prolínáním jednotlivých pojmů a tím souvisejícími nejasnostmi při práci s materiálem a vyhodnocením keramických souborů (např. výroba keramiky nálepem-válečková technika-obtáčení; obtáčení jako dotváření nádob vyrobených z válečků-jako způsob vytváření nádoby pomocí formy na kruhu). Komplikace vyvstávají také v př́ípadě nesprávného užití některých pojmů nebo při překladu z cizojazyčných studií.

Jedním ze základních termínů, které je nutné si při studiu technologie definovat, je hrnčířský kruh. V odborné literatuře se lze setkat s několika výrazy označujícími různé formy hrnčíŕských kruhů. Pojmem hrnčířský kruh se obecně, jak v české tak zahraniční literatuře, rozumí kruh, který je schopen vyvinout rychlé otáčky a zároveň je poměrně dlouhou dobu udržovat. V rovině současného hrnčířství se jedná o elektrický 


\begin{tabular}{|c|c|c|c|c|}
\hline ČESKY & ANGLICKY & NĚMECKY & POLSKY & FRANCOUZSKY \\
\hline \multicolumn{5}{|c|}{ Techniky výroby a úpravy } \\
\hline Vymačkávání & Pinching & Modelierung & $\begin{array}{l}\text { Ugniatanie z jednej } \\
\text { kawalka }\end{array}$ & Modelée \\
\hline Spojování plátů & Slab building & - & - & - \\
\hline Vytahování & Drawing & Ziehen & - & Étirage \\
\hline Hnětení ve formě & Molding & \begin{tabular}{|l|} 
Formgebung, \\
Formhilfe geformen
\end{tabular} & $\begin{array}{l}\text { Wygniatanie na } \\
\text { formie }\end{array}$ & Moulée \\
\hline Stáčení z válečků & Coiling & Schrittgleit-Technik & $\begin{array}{l}\text { Waleczkowa } \\
\text { ugniatania }\end{array}$ & $\begin{array}{l}\text { Façonnage aux } \\
\text { columbine }\end{array}$ \\
\hline Stáčení z kroužků & Ring building & Ringvulsten & \begin{tabular}{|l|} 
Waleczkowo- \\
pierścieniowa
\end{tabular} & - \\
\hline Stáčení na kruhu & Wheel-Coiling & Gleitband-Technik & $\begin{array}{l}\text { Technika slizgowo- } \\
\text { tasmowa }\end{array}$ & Le colombin tourne \\
\hline Vytáčení & $\begin{array}{l}\text { Throwing, } \\
\text { Wheel-Throwing }\end{array}$ & Drehung & Toczenie na kole & Tournage \\
\hline Nastavování & - & - & Nakladanie & - \\
\hline Obtáčení & Thuring & \begin{tabular}{|l|} 
Abdrehung, \\
Nachdrehung
\end{tabular} & - & Tournassage \\
\hline Tvarování na kruhu & Wheel-shaping & - & - & - \\
\hline Dokončování na kruhu & Whee-finishing & - & - & - \\
\hline Vytloukání & Beating & - & - & - \\
\hline Škrábání & Scraping & - & - & - \\
\hline Hlazení & Smoothing & - & - & - \\
\hline Leštění & Polishing & - & - & - \\
\hline Aplikace & Applique & - & - & - \\
\hline Vyrývání & Incising & - & - & - \\
\hline Otiskování & Impresing & - & - & - \\
\hline Řezba & Carving & - & - & - \\
\hline Namáčení & Wetting & & & \\
\hline \multicolumn{5}{|l|}{ Postupy při výrobě } \\
\hline Centrování & Centering & - & - & Centrage \\
\hline Otevírání & $\begin{array}{l}\text { Opening, } \\
\text { hollowing }\end{array}$ & - & - & Creusement \\
\hline Vytahování & Lifting & - & - & Montées \\
\hline Tvarování & Shaping & - & - & Façonnage \\
\hline Zužování hrdla & Collaring & - & - & - \\
\hline Vyrovnávání & Levelling & - & - & - \\
\hline Odřezávání & Cutting & - & - & Retirer \\
\hline Sejmutí & Removal & - & - & Retrait \\
\hline
\end{tabular}




\begin{tabular}{|l|l|l|l|l|l|}
\hline \multicolumn{2}{|c|}{ ČESKY } & ANGICKY & NĚMECKY & POLSKY & FRANCOUZSKY \\
\hline Části nádob & Roughout & - & - & Ébauche \\
\hline Nárys (dutý tvar) & - & - & Préforme \\
\hline $\begin{array}{l}\text { Polotovar (hotový tvar } \\
\text { bez úpravy povrchu) }\end{array}$ & Preform & & & Base \\
\hline Dno & Base & Bodenrand & - & Panse, corps \\
\hline Tělo & Body & Korpus & - & Bord \\
\hline Okraj & Rim, collar & Rand & - & \\
\hline
\end{tabular}

Tab. 1. Slovník obsahující termíny týkající se výrobních technik a úprav povrchu, postupů při výrobě a částí nádob.

Tab. 1. Vocabulary of terms concerning the production techniques and surface finish, production procedures and parts of vessels.

mechanický hrnčířský kruh, z archeologického pohledu většinou o kruh poháněný údery nohou. Dosáhnout vysokých otáček jsou však schopny také kruhy roztáčené holí nebo rukou. $\mathrm{V}$ archeologii se u tohoto typu kruhu lze setkat s označením rychle rotující kruh, nožní nebo kopací kruh, případně šprušlák. Rychle rotující kruh je založen na systému dvou kol na jedné ose. Spodní, větší, kolo slouží u kopacího kruhu k vytváření otáček údery nohou a zároveň jako setrvačník, který otáčky udržuje. Na podobném principu funguje také anglicky zvaný stick-wheel. Jedná se o kruh, který má obě kola ve stejné úrovni a je otáčen za pomoci hole odrážející se od většího vnějšího kola, zatímco na vnitřním menším kole je formována nádoba. Pravidelné rychlé otáčky kruhu umožňují vytvářet nádoby vytáčením z jednoho kusu hlíny. Na jednodušším principu funguje tzv. točna někdy turneta, v archeologii také pomalu rotující nebo ruční kruh. Točna má pouze jedno kolo na ose, které je roztáčeno rukou. Točna poskytuje pomalejší a nepravidelné otáčky, avšak i na ní je v některých případech možné vytáčet nádoby z jednoho kusu hlíny. Setrvačnost u tohoto typy kruhu není tak vysoká a formování nádob je častěji přerušeno roztáčením kola. Dalším prostředkem, který ulehčuje výrobu nádob, představuje podložka, kterou lze podle potřeby pootáčet (Nekuda - Reichertová, 33-34; Ludikovský 1960,
66-68; Barěs - Lička - Růžičková 1981, 178; Černohorský 1952, 224; Rada 1997, 36-37). V rámci archeologie nebo etnologie se může jednat např. o plochý kámen, dřevěnou desku, část nádoby, proutěný koš nebo také tkaninu (Shepard 1956, 57; Holmes 1901, 399).

Dalším důležitým a běžně užívaným je termín válečková technika. U tohoto pojmu se však lze často setkat s jeho mnohotvárným využitím. Obecně je možné termín válečková technika, definovat jako postup, kdy je tvar nádoby vytvořen vrstvením válečků a následně je upraven tak, aby spoje mezi jednotlivými válečky byly co nejméně znatelné. Důkladné spojení válečků je důležité zejména z funkčního hlediska, ale nelze opomenout také estetiku výsledné nádoby. Válečky mohou mít podobu jednotlivých kroužků potřebného průměru, které jsou skládány na sebe, nebo jednoho dlouhého válečku, který je postupně navijen do požadované výšky a tvaru v podobě spirály. Úprava válečků do finálního výrobku je rovněž možná několika způsoby. Prvním je statické rozetření hmoty válečků nástrojem nebo prsty do mezer mezi jednotlivými válečky. S tímto postupem se setkáváme zejména u pravěké keramiky, kde se využití rotace nepředpokládá (Bareš - Lička - Růžičková 1981, 176). Další možností úpravy válečků je využití rotace, díky níž dochází k rozvolnění hmoty válečků a jejich spojení. $\mathrm{V}$ archeologické literatuře se pro tento postup 
výroby ujal termín obtáčení. Obtáčené nádoby se objevují od rané doby dějinné a ve většině př́ípadů je jejich výroba spojována s pomalu rotujícím kruhem (Nekuda - Reichertová 1968, 33; Ludikouský 1960, 74-75; Polla 1962, 95). Méně často je možné se setkat s pojmem obtáčení jako s procesem vytváření nádob z jednoho kusu hlíny na rychle rotujícím kruhu s využitím formy, kdy se z vnitřku formy keramická hmota ubírá (Bareš - Lička - Růžičková 1981, 179). V české archeologické literatuře často dochází k prolínání termínů válečková technika a obtáčení, kdy někteří badatelé užívají pojem válečková technika taktéž pro obtáčení a naopak. Např. J. Macháček (2001, 22) pod vlivem polských autorů (Buko 1990) užívá termínu obtáčení slabě formující, kdy nádoba byla upravována obtáčením bez využití rotace kruhu, a obtáčení silně formující, kdy docházelo vlivem rotace $\mathrm{k}$ přemistování hlíny ve stěně nádoby.

V porovnání s hrnčířskou terminologií pak u termínu obtáčení v archeologii dochází k záměně významu slova. $\mathrm{Z}$ archeologického hlediska se jedná o primární výrobní techniku keramických nádob. Z hrnčíŕského pohledu je obtáčení proces úpravy povrchových vlastností morfologicky již hotového výrobku, který nejčastěji probíhá v kožovitém (případně téměř suchém) stavu. Nádoby v kožovitém stavu jsou částečně proschlé tak, aby se při manipulaci nedeformovaly jejich stěny, ale zároveň je hlína dostatečně měkká pro úpravu povrchu. Při obtáčení jsou nádoby v kožovitém stavu opětovně nasazovány na kruh a pomocí nástrojů, tzv. obtáčecích oček/obtáčedel, je možné upravit nerovnosti na vnějším i vnitřní povrchu nádoby. Obtáčením dochází $\mathrm{k}$ drobné úpravě tvaru odebíráním hlíny (za předpokladu, že stěna výrobku je dostatečně silná), k vytvoření podední apod. Podedním se rozumí vyvýšená část dna, která nesmí být glazována, aby se nádoba nepřilepila k peci (samozřejmě je možné nechat neglazovanou celou plochu dna, ale tím by mohlo docházet k postupnému prosakování tekutin během používání předmětu). Z tohoto pohledu se tedy nejedná o formovací techniku nýbrž o techniku úpravy povrchu.

\section{Výrobní techniky}

Techniky, které se objevují v archeologické literatuře, jsou odvozeny zejména z poznatků etnologie a etnoarcheologie. Mnohé z nich lze $\mathrm{v}$ téměř nezměněné podobě nalézt také v současném hrnčířství a své místo zaujímají rovněž v rámci experimentální archeologie.

Postup výroby každé nádoby lze rozdělit na dvě základní etapy - primární formování a sekundární formování. Během primárního formování je z hrudky hlíny vyroben základní tvar připomínajícího konečnou nádobu (tzv. základní dutý tvar). Důležité je, aby bylo dokončeno dno nebo okraj, které po zaschnutí do kožovitého stavu vytváří dostatečnou stabilní podporu pro další manipulaci s nádobou. Mezi primární formování lze řadit techniky vytáčení, navíjení válečků, spojování plátů, vymačkávání, tvarování do formy a vytahování. Sekundárním formováním (nebo také technikami konečné úpravy) jsou dány rozměry jednotlivých částí a je definován konečný tvar, čímž vzniká tzv. polotovar. Sekundární formování může probíhat ihned po dokončení nádoby, v kožovitém stavu nebo také během sušení výrobku. Mezi používané techniky patří obtáčení, seškrabávání, seřezávání, vytloukání a řezání. Během třetí fáze dochází k povrchovým modifikacím. Povrch nádob může být upraven např. hlazením, leštěním, obtáčením, řezbou, plastickými aplikacemi. Zároveň je možné využít materiály složením odlišné od těsta, jako jsou pigmenty, glazury a organické nátěry (Rye 1981, 62; Courty - Roux 1995, 22-23; Méry - Delaleuf - Leeuw 2010, 54).

Během výroby nádob jsou využívány různé způsoby rotace a tlaků, jimiž hrnčír působí na 
vytvářenou nádobu. Formovat nádoby lze staticky, pomocí přerušované nebo nepřetržité rotace. Během statického formování nádoby není využita žádná rotace, ale není vyloučena možnost umístění nádoby na podložce, kterou lze podle potřeby pootáčet pro snadnější manipulaci zejména s velkými nádobami. Přerušovaná rotace zajištuje pomalé a nesouvislé otáčení, kdy je na hlínu vyvíjen nerovnoměrný tlak. $\mathrm{K}$ nerovnoměrnému tlaku dohází např. ve chvíli, kdy hrnčír v jednom okamžiku jednou rukou otáčí točnou, zatímco druhou rukou vyvíjí tlak na nádobu. Nepřetržitá rotace je spojena s rovnoměrným tlakem působícím na tvarovanou nádobu a ve většině případů s využitím hrnčíř ského kruhu. I když jak už bylo řečeno, rovnoměrného tlaku lze dosáhnout i na některých dalších typech kruhu a rovněž bez rotačního zařízení, např. obcházením hrnčíře kolem nádoby. Hrnčíř v takovém případě při výrobě nádob využívá obě ruce. Zdrojem energie je právě kontinuální tlak rukou v kombinaci s kinetickou rotační energií kruhu. Na nádoby dále působí také tahová síla, která v některých případech způsobuje tzv. smykovou deformaci. K deformaci dochází např̀ v př́ípadě, kdy je tahová síla př́liš velká vzhledem $\mathrm{k}$ síle stěny nádoby a ta se pak pod jejím vlivem deformuje.

\subsection{Vymačkávání}

Vymačkávání je pravděpodobně nejjednodušší technikou, která nevyžaduje žádné speciální dovednosti. Nádoba je tvarována stlačováním kusu hlíny mezi prsty a palcem jedné ruky nebo mezi prsty obou rukou. Stěny jsou ztenčovány a zvyšovány rytmickým opakováním se stlačení hlíny mezi prsty, přičemž je nádoba v rukou pootáčena. Malé nádoby mohou být touto technikou vyrobeny celé. U větších nádob je kombinována s dalšími technikami a využívá se spíše pro výrobu dna nádoby nebo ke zmenšení nerovností ve stěně hotového základního tvaru (v takovém př́ípadě je vymačkávání užito jako sekundární technika). Při hnětení nádoby lze vyčerpanou původní hmotu nastavit přidáním nové. Nastavování může probíhat jak v surovém tak také v kožovitém stavu (Štajnochr 1998, 98). Vymačkávání se řadí mezi statické techniky, ale není vyloučeno umístění nádob na otočné podložce, která usnadňuje manipulaci s nimi (Rye 1981, 70; Holubowicz 1965, 15).

\subsection{Spojování plátů}

Opět se jedná o statickou techniku výroby, pro niž nejsou potřeba žádné speciální dovednosti. Hliněné pláty jsou většinou formovány stlačováním na ploché podložce pomocí různých válků nebo pomocí rukou do potřebných rozměrů. Hrany plátů jsou spojovány stlačením a „rozmazáním“ hlíny v místě spoje, aby nedocházelo k praskání spojů během sušení a výpalu. Tato technika je vhodná zejména pro výrobu velkých nebo pravoúhlých nádob a kachlů (Rye 1981, 71; Hofer 2010, 16).

\subsection{Tvarování do formy}

Další technikou řadící do skupiny statického formování je tvarování do formy. Samotná výroba nádob tvarováním do formy není př́liš náročná a zvládne ji po krátkém „zaškolení“ téměř každý (Arnold 1999). Jistá manuální zručnost je vyžadována pouze při výrobě forem. Během tvarováním je plastické těsto vtlačováno do formy nebo naopak na formu. V případě vtlačování do formy tvoří forma vnější povrch, v druhém případě vnitřní povrch nádoby. Formy jsou vyráběny z hlíny a z důvodu delší životnosti vypalovány. Porézní formy pomalu absorbují vlhkost z formované hlíny a díky tomu nádoba pomalu schne. 


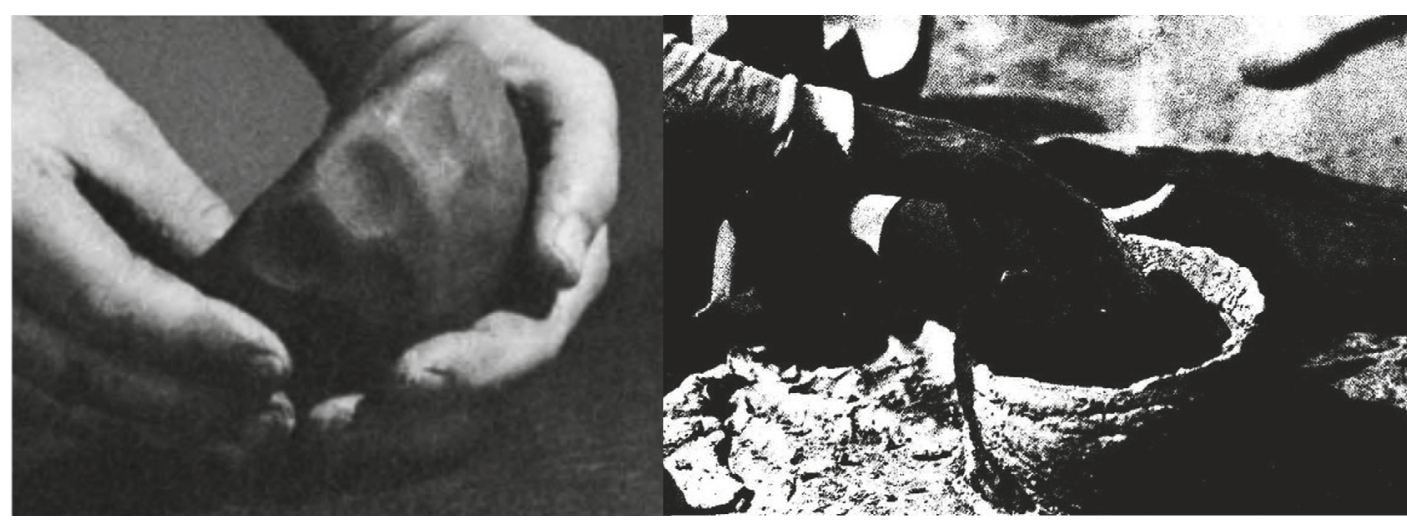

Obr. 1. Technika vymačkávání (podle Rye 1981; Schneider 1991).

Fig. 1. Pinching (after Rye 1981; Schneider 1991).

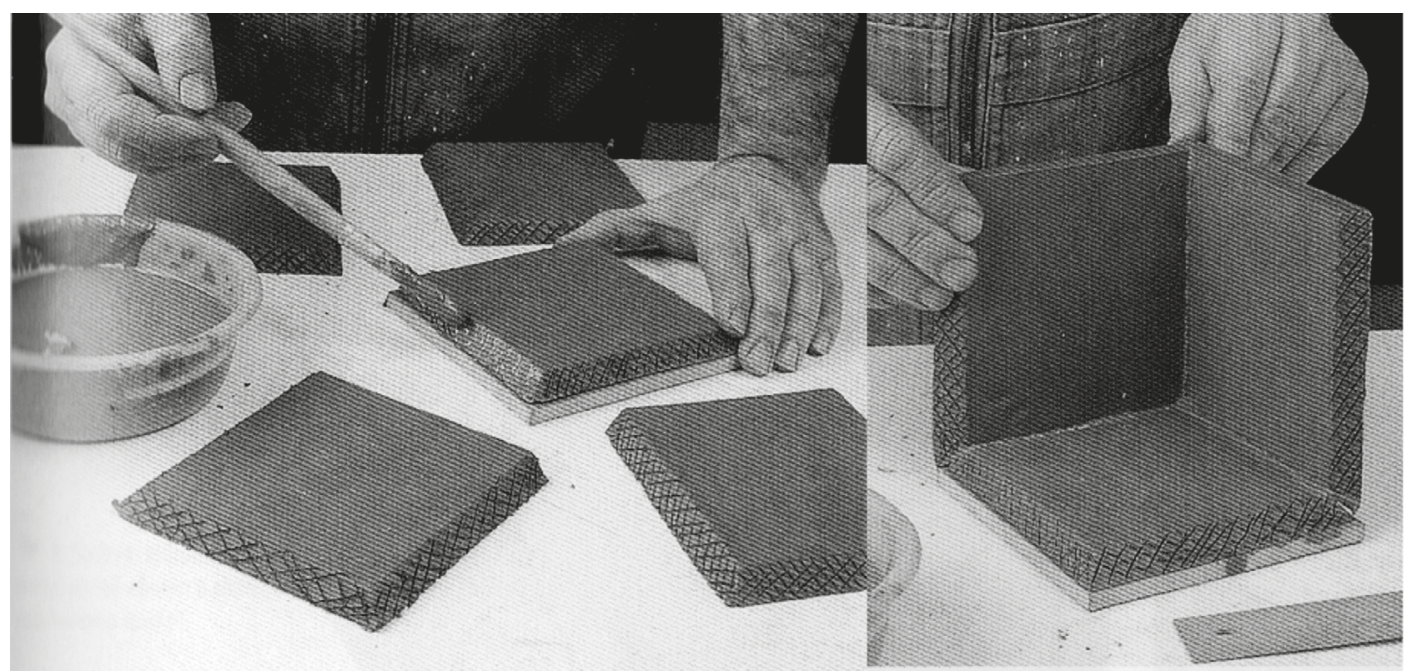

Obr. 2. Technika stavení z plátů (podle Chavarria 1999).

Fig. 2. Slab building (after Chavarria 1999).

Aby bylo možné nádobu dobře od formy od- Tvarovací formy mohou být rovněž zdobeny dělit, bývá forma vysypána jemným pískem např. rytím, kdy na povrchu nádoby vzniká nebo popelem. Při použití forem je také mož- reliéfní výzdoba, nebo reliéfem, přičemž na né uplatnit více technik formování nádoby. povrchu nádoby vznikne vhloubená výzdoba. Hlína může být do formy vtlačována pomocí Tato technika je velice efektivní zejména porukou nebo různých kamenných a dřevěných kud má nádoba složitý plastický dekor (Rye nástrojů. Je možné umístit formu na kruh 1981, 81; Holubowicz 1965, 15; Shepard 1965, a za pomoci otáček hlínu do formy zatočit. 63; Hofer 2010, 16). 


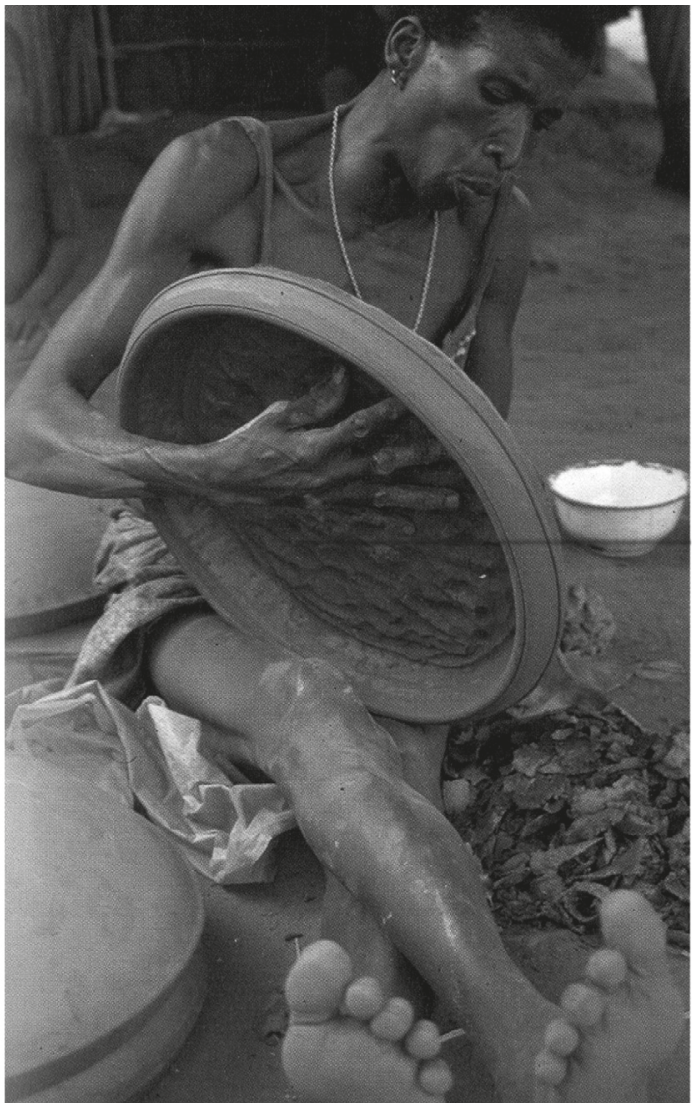

Obr. 3. Technika tvarování do formy (podle Virot 2005).

Fig. 3. Mould pressing (after Virot 2005).

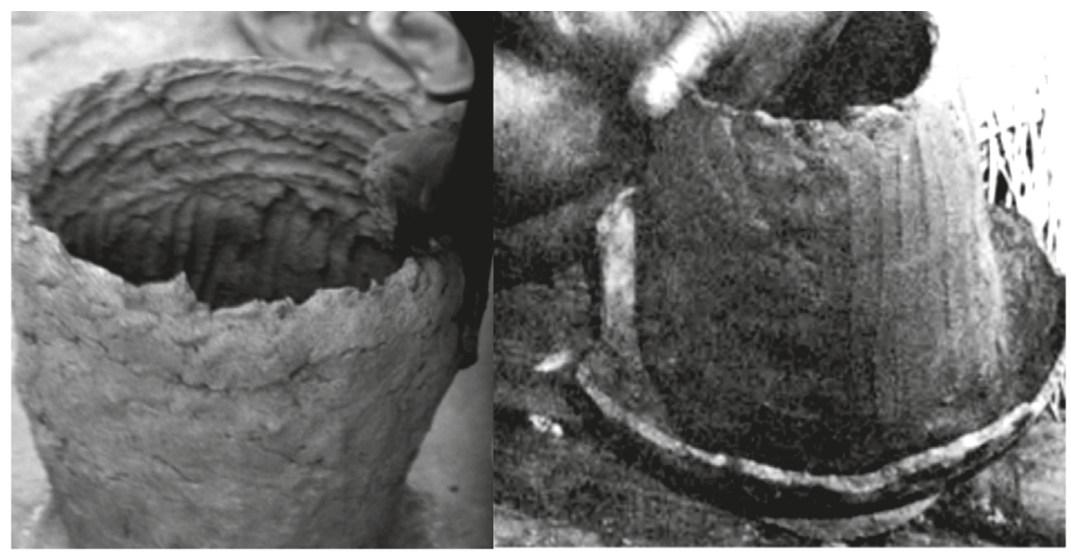

Obr. 4. Technika vytahování (podle Virot 2005; Rye 1981).

Fig. 4. Lifting (after Virot 2005; Rye 1981). 


\subsection{Lití}

Technika lití je spíše moderní metodou výroby keramických nádob. K tvarování využívá většinou sádrových forem a tzv. licí břečky, tedy ztekucené hrnčířské hlíny. Forma pohltí přebytečnou vlhkost licí břečky, která se tak přichytí k jejím stěnám a zbývající licí břečka je následně z nádob odstraněna. Tímto zpơsobem lze vyrobit předměty s rovnoměrně silnými stěnami bez nerovností a dalších stop výroby (Chavarria 1999, 102-103).

\subsection{Vytahování}

Vytahování je jednou z technik, kterou lze opět vyrábět nádoby bez použití rotace (statické formování) a speciálních dovedností. Hrudka hlíny je otevřena úderem pěsti a stěny jsou následně vytvářeny stlačováním hlíny mezi prsty a současně roztahováním těsta směrem nahoru. Pomocí vytahování je tak možné dosáhnout i velkých rozměrů nádob (Rye 1981, 73). Tuto techniku je také možné využít v kombinaci se stáčením z válečků, kdy dochází k nastavování nádoby přidáním válečků a jejich vytažením (Livingstone Smith - Van der Veken 2007-2009, 145).

\subsection{Tvarování nádob z válečků}

Do této skupiny patří techniky, jejichž základním prvkem jsou válečky následně spojované do tvaru nádoby. Válečky jsou vyrobeny horizontálně hnětením mezi prsty nebo vertikálně válením na pevné podložce a poté vrstveny na sebe. Nakonec jsou rozhněteny do stran, aby došlo k lepšímu spojení těsta. Průměr válečků se liší podle velikosti nádoby od několika milimetrů až po několik centimetrů.

\subsubsection{Stáčení válečků}

Tato technika je v české literatuře známá jako válečková technika nebo technika nálepu. Nádobu lze stáčením válečků vyrobit celou nebo v kombinaci s dalšími výrobními technikami, např. spodní část nádoby může být vytočena na kruhu a vrchní část může být dokončena přidáním jednoho nebo více válečků. Tento postup je možné uplatnit zejména při výrobě velkých nádob, protože manipulace s tak velkým množstvím hlíny na kruhu by byla velmi obtížná. Tato technika rovněž nemá vysoké nároky na vytvářecí hmotu. Jelikož nepodléhá takové úrovni tažení jako hlína během točení, umožňuje využití méně plastických jílů. Nevýhodou je, že stáčení válečků je pomalejší než technika vymačkávání a vazba jednotlivých válečků je častým zdrojem vad, jako jsou praskliny vzniklé během sušení nebo výpalu.

V etnologické literatuře se můžeme setkat s odlišováním techniky stáčení (angl. coiling), kdy jsou válečky dlouhé a jsou na sebe vrstveny ve formě spirál a stavění z kroužků (angl. ring building). Výhodou stáčení z kroužků na rozdíl od stáčení spirál je, že se okraj drží v jedné rovině a není nutné ho na konci výrobního procesu srovnávat. V archeologickém materiálu je však odlišení obou technik téměř nemožné a proto jsou oba termíny využívány jako synonyma (Rye 1981, 67; Holubowicz 1965, 15; Sheprad 1956, 58-59).

\subsubsection{Stáčení na kruhu}

Jedná se o techniku kombinující stáčení válečků s tvarováním na kruhu. Základní tvar nádoby je vyroben pomocí navíjení válečků a poté dochází díky využití energetického potenciálu kruhu ke změně morfologie stěn. Tato technika ovšem vyžaduje nezbytný rozvoj motorických dovedností. V české archeologické literatuře je 


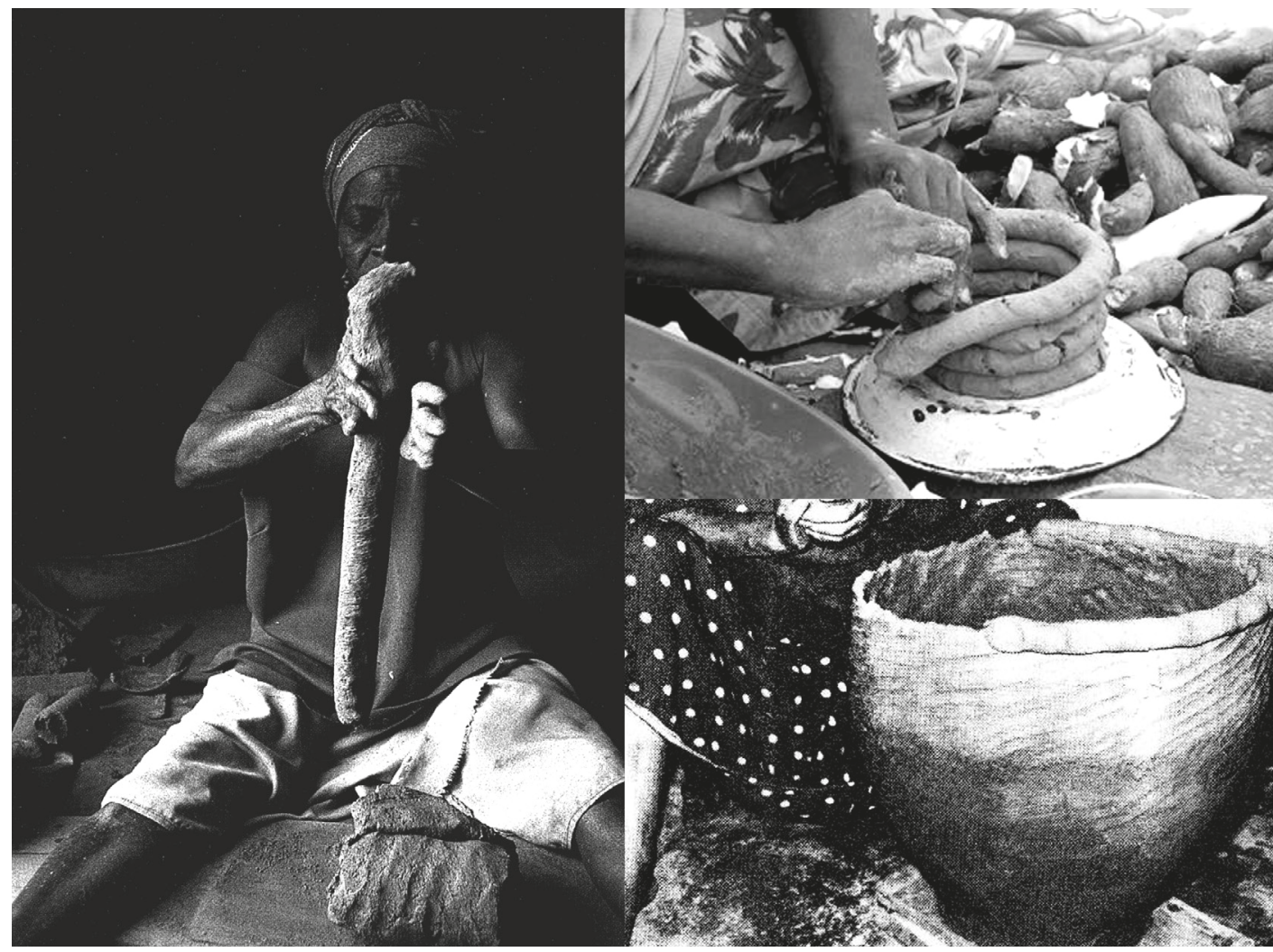

Obr. 5. Technika stáčení z válečků (podle Virot 2005; Livingstone Smith - Van der Veken 2009; Gruner 1988).

Fig. 5. Coiling (after Virot 2005; Livingstone Smith - Van der Veken 2009; Gruner 1988).

právě tato technika spojována s pojmem obtáčení. Francouzská badatelka Valentine Roux rozlišuje u stáčení na kruhu čtyři základní fáze výroby a tím i čtyři možné způsoby podle toho, v jaké fázi je do výroby zapojena rotace. Základní válečky jsou vyrobeny staticky bez ohledu na způsob jejich další úpravy. První fází je tvarování válečků do základního dutého tvaru (tím je určen průměr budoucí nádoby a síla stěny). Následuje připojování/spojování válečků, ztenčování stěny a tvarování polotovaru.

Při použití prvního způsobu výroby jsou válečky tvarovány, připojeny i ztenčeny nesouvislým tlakem a teprve tvarování těla nádoby je dokončeno pomocí rotace. Druhý způsob zahrnuje postup, při němž jsou válečky vytvarovány a spojeny nesouvislým tlakem a jejich následné ztenčování a tvarování stěny je provedeno pomocí rotační energie kruhu. U třetího způsobu není rotace využita pouze při tvarování válečků. Se čtvrtým způsobem dochází k využití rotační energie kruhu ve všech fázích výroby nádoby. Výsledkem této výrobní techniky jsou nádoby vysoké kvality, které díky silné deformaci válečků umožňují hrnčírí získat výrobky bez známek spojování (Roux - Courty 1998, 748-751; Roux 2009, 197). 


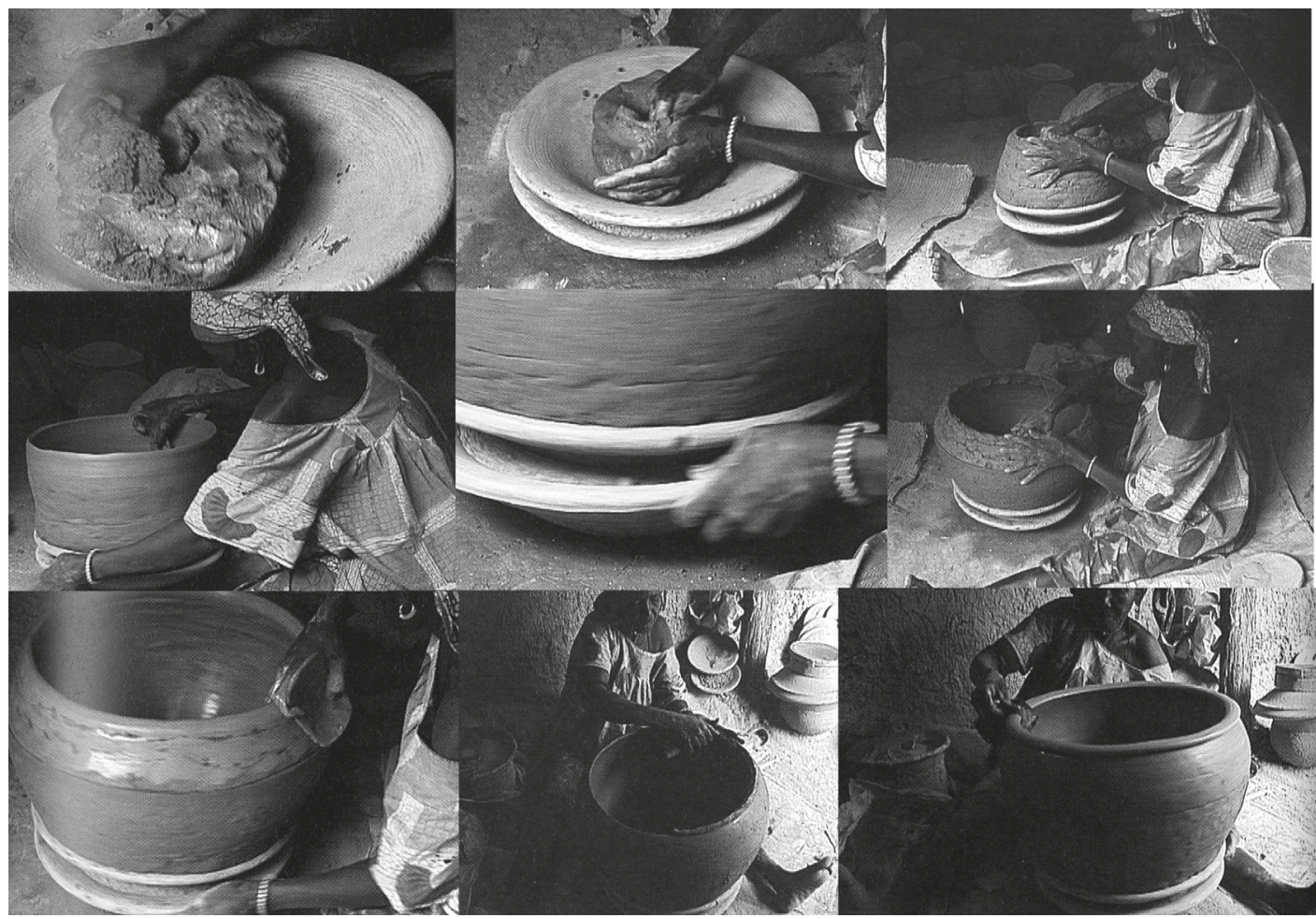

Obr. 6. Technika stáčení na kruhu (podle Virot 2005).

Fig. 6. Wheel coiling (after Virot 2005).

\subsection{Vytáčení na kruhu}

Technika vytáčení je spojena s využitím hrnčírsského kruhu a neustálou pravidelnou rotací k tvarování masy hlíny. Na rozdíl od techniky stáčení na kruhu je při vytáčení vyroben i základní tvar, který je dále tvarován. Tato technika ale vyžaduje speciální motorické dovednosti velmi náročné na naučení. Na druhou stranu dochází k mechanizaci celého výrobního procesu a výroba se zrychluje a zkvalitňuje. Na techniku vytáčení nádob na kruhu se tak váže masová produkce keramiky a rozvoj specializace řemesla (Rye 1981, 74; Courty - Roux 1995, 17; Roux 2009, 197).

Proces vytáčení rovněž zahrnuje několik fází, z nichž některé zanechávají charakteristické znaky na finálním výrobku (viz. níže). První fáze je označována jako smáčení. Aby mohla být hlína na kruh umístěna, musí být hlína i hlavice kruhu suchá. Ovšem během všech následujících kroků výroby je nutné, aby hrnčířovy ruce a také hlína byly mokré. Voda v tomto případě funguje jako mazivo a umožňuje hlíně jemně procházet rukama hrnčíře. Druhým krokem je centrování hroudy hlíny, která musí být na kruhu umístěna tak, aby kroužila koncentricky s osou kruhu. Nesprávné vycentrování působí problémy v dalších fázích výroby a výsledná nádoba není symetrická. Než je možné přistoupit k tvarování nádoby, musí být ve středu hroudy vytvořen otvor. Tato fáze se označuje jako otevírání. Při následujícím vytahování hrnčíř vyvíjí tlak uvnitř i vně otvoru a vytahuje stěnu směrem vzhůru. Tímto postupem jsou stěny zvyšovány a ztenčovány a je získán základní tvar. Během další fáze, 


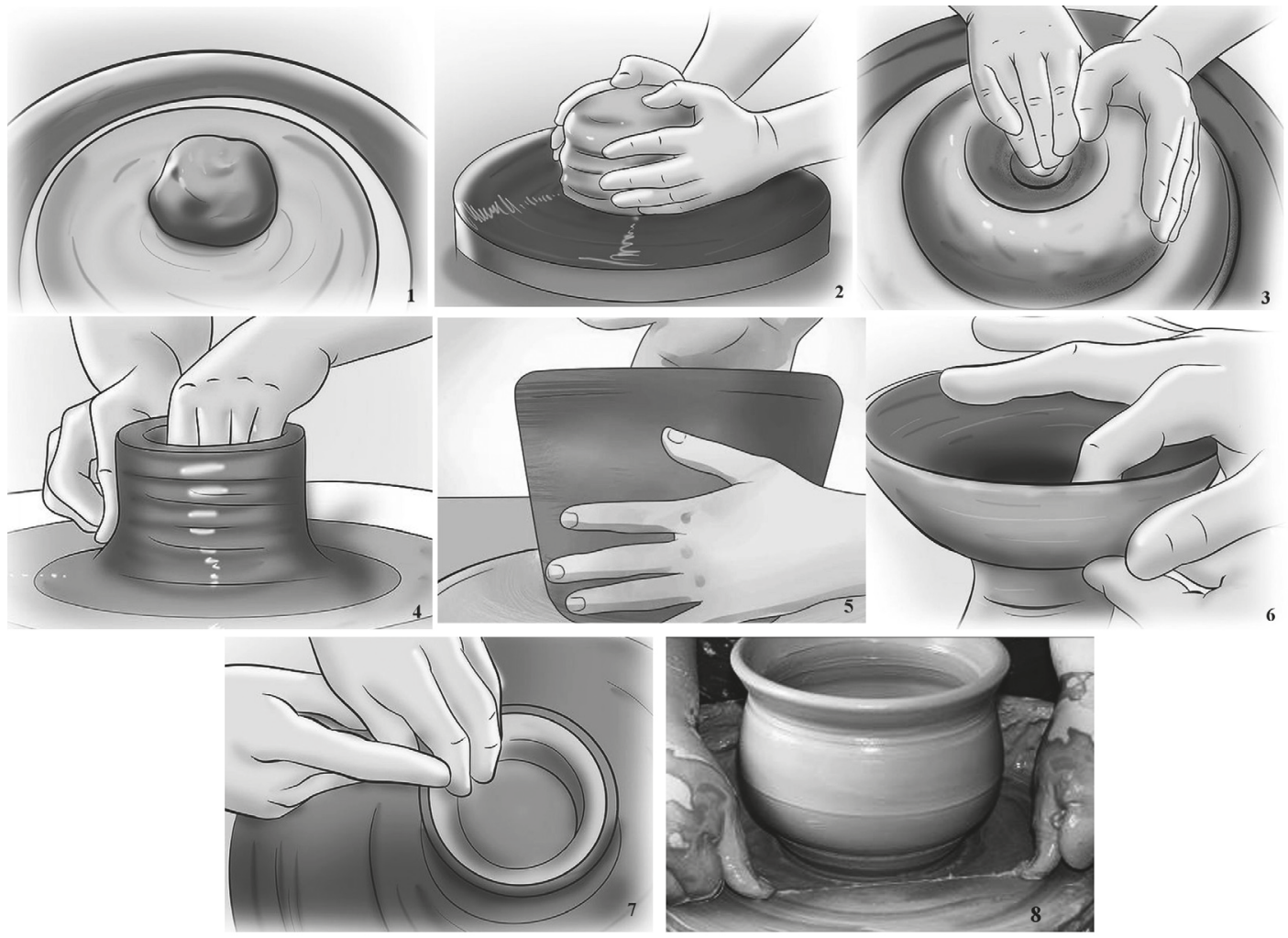

Obr. 7. Technika vytáčení na kruhu (dostupné z www.wikihow.com, www.pottery.about.com).

Fig. 7. Wheel throwing (available from www.wikihow.com, www.pottery.about.com)

tvarování, dostává základní tvar konkrétní metrické a morfologické vlastnosti finální nádoby. Zkušený hrnčír je schopen tvarování už ve fázi vytahování, čímž významně zkrátí čas potřebný pro vytvoření jedné nádoby. Zúžením průměru $\mathrm{v}$ některém bodě nádoby dochází $\mathrm{k}$ vytvoření hrdla. Následují kroky spojené s vyrovnáním tvaru (nejčastěji zaříznutí nerovného okraje), odříznutí nádoby z hlavice kruhu a její sejmutí. Závěrečný krok, tedy sejmutí z kruhu, vyžaduje značné dovednosti, nebở ředěním plastické hlíny vodou během točení je nádoba choulostivější na deformace. Nádoba a hrnčířovy ruce musí být v této fázi opět suché (Hanykýř a kol. 2011, 199-211; Chavarria 1999, 109-118; Dolors 2003, 51-57).
Techniky vytáčení nádob na kruhu a stáčení na kruhu produkují nádoby velmi podobných kvalit. Obě techniky zároveň mají vysoké nároky na motorické dovednosti hrnčíře vyžadující proces učení a opakované praxe. Dovednosti, které musí hrnčíř ovládat, jsou zejména usměrňování tlaku obou rukou, stabilita předloktí, změna frekvence tlaků podle plasticity hlíny, rychlosti kruhu a konkrétní fáze procesu vytváření a také stálost a pravidelnost vyvíjených tlaků. Odlišnost metod spočívá nejen v operacích, které je nutné vykonat, aby mohl vzniknout finální produkt, ale také ve využití kruhu. Během stáčení na kruhu není nutné, aby rotace kruhu přesáhla 80 otáček za minutu a to bez ohledu na velikost nádoby. $\mathrm{K}$ výrobě nádoby tedy může 
být využita otočná podložka nebo ruční kruh. Naopak k vytáčení nádob jsou potřebné pravidelné otáčky s rychlostí cca 150 otáček za minutu. Hrnčířský kruh s vyššími otáčkami lépe odolává tlakům hrnčířových rukou zejména při centrování hlíny (Roux 2009, 197-198).

\section{Stopy výrobních technik}

Každý způsob výroby keramiky zanechává na výrobku stopy, na jejichž základě lze určit možný způsob výroby dané nádoby. Některé skupiny stop je možné pozorovat makroskopicky a to jak na povrchu nádob, tak lomu střepu. Viditelnost stop však není vždy stejná a jejich interpretace nemusí být úplně jednoznačná. Problémy způsobuje např. př́liš pečlivé provedení keramiky, kdy úpravy povrchu zakryjí výrobní stopy. Komplikace způsobuje také fragmentarizace archeologické keramiky. Menší fragmenty mohou být špatně orientovány a naopak u příliš zachovalých nádob nebo slepených kusů nemusí být některé stopy viditelné. Také ne všechna historická období jsou pro studium výrobních technologií př́hodná. Nutností je dostatečně velký reprezentativní soubor, na kterém lze výrobní stopy interpretovat (Neumannová 2013; Livingstone Smith 2010, 11; Vukovic 2014, 180-181). Makroskopické studium stop výrobních technik by mělo brát na zřetel zejména změny tloušťky, povrchové nepravidelnosti a orientaci prríměsí a pórů (Livingstone Smith 2010, 11). Při validaci interpretovaných stop je taktéž možné využít mikroskopické analýzy, které umožňují analyzovat vnitřní strukturu střepu, a experimentální archeologii (Dupont-Delaleuf 2011, 41; Roux Courty 1998, 750-754; Rye 1981, 62).

Při zjištování způsobu výroby keramiky je dobré posuzovat větší části nádoby nebo alespoň střepy z jejich různých částí. Pro stanovení techniky výroby nádob je pak určující zejména výdut (Courty - Roux 1995, 30). Převážně ve starší české a slovenské literatuře je možné se setkat s určováním technologie výroby podle dna nádoby (Polla 1962, 100-101; Zápotocký 1979, 31). Dno však, častěji než jiné části, může být vyrobenou jinou technikou než zbytek nádoby a ani stopy odřezávání nebo podsýpky na dně nemohou být určující. Podsýpka, nejčastěji jemný písek nebo popel, slouží k tomu, aby se nádoba nepřilepila ke kruhu. Z této premisy pak plyne v české archeologii dlouho tradovaný závěr, že nádoby, jež mají na dně stopy podsýpky nebo tzv. hrnčíŕské značky byly vyrobeny „obtáčením“ na pomalu rotujícím kruhu a naopak nádoby se stopami odříznutí, at už strunou nebo nožem, musely být vyrobeny vytáčením na rychle rotujícím kruhu. Ne všechny obtáčené nádoby ale stopy po podsýpce mají a naopak i takto vyrobené nádoby mohou mít na dně stopy odřezání nebo nevykazují žádné stopy. Experimenty ukázaly, že je rovněž možné vytáčet nádoby na rychle rotujícím kruhu s posýpkou na dně. Během experimentální výroby takových nádob byl vytočen dutý tvar, do něhož byla nasypána podsýpka a následně materiál ze stěn stočen do dna (Bernhardt 2011, 71-72). Otázkou ale zůstává, zda není tento postup zbytečnou komplikací při výrobě a jakou funkci by v takovém případě podsýpka plnila. Hrbolatého povrchu po podsýpce se dá docílit velmi jednoduše a neúmyslně např. položením právě vytvořené měkké nádoby na dřevěnou desku, která je posypaná pískem nebo popelem, na níž nádoba schne. V tomto případě pak podsýpka opravdu plní funkci antiadhezního materiálu a nádoby se díky písku se k podložce nepřilepí. Ani keramické značky nemusí být nutně spojovány pouze s obtáčením. Experimentálně bylo vyzkoušeno vytáčení nádob na rychle rotujícím kruhu s dřevěnou hlavicí, v níž byly vyřezané repliky středověkých keramických značek, které následně zanechaly reliéf na dně nádoby (Bočková a kol. 2014, 124-128). 


\subsection{Stopy po vymačkávání nádob}

Dna nádob vyrobená touto technikou mohou mít dvě formy. První je plochá a je zde patrné spojení s výdutí. Druhá forma dna je konvexní a nemá viditelné spojení mezi dnem a spodní částí těla nádoby. U vymačkávaného dna lze na spodní části, na pohled nebo na dotek, identifikovat drobné prohlubně uspořádané vedle sebe nebo částečně přes sebe. $\mathrm{V}$ některých případech se může objevit také otisk prstu (DupontDelaleuf 2011, 43, 45-47).

$\mathrm{Na}$ těle nádob nezanechává většinou tato technika žádné signifikantní stopy. Stěny nádob mohou být pravidelné nebo se v jejich síle projevují pravidelné mělké vroubky, jejichž tvar závisí na naklonění hrnčířových prstů při výrobě nádoby. Objevovat se mohou drobné rýžky nepravidelného tvaru na povrchu (Rye 1981, 70; Rzeznik 1995, 66-67).

\subsection{Stopy po technice stavění z plátů}

Zachování výrobních stop je závislé na sekundárních úpravách povrchu a také na způsobu výroby plátů. Pokud byl plát uválen na rovné podložce, je povrch rovný a hladký. V síle stěny se objevují nepravidelné odchylky (Rye 1981, 71).

\subsection{Stopy tvarování do formy}

Nádoby tvarované do formy mají odlišné stopy na vnějším a vnitřní povrchu s ohledem na to, zda forma tvoří jejich vnější nebo vnitřní povrch. Jedna strana kopíruje povrch formy (obr. 9b) a objevují se na ní příčné rýhy, které jsou výsledkem kontaktu hlíny s materiálem formy nebo antiadhezní vrstvou (popelem, drceným jílem apod.; Dupont-Delaleuf 2011, 47). Druhá strana (obr. 9a) ukazuje znaky spojené s tvarováním, např. mělké žlábky po tlaku prstů. Varia- bilita v síle stěny se projevuje na straně, která je tvarována. U vícedílných forem je charakteristický výskyt švů v částech, kde se spojují jednotlivé části formy (Rye 1981, 81).

\subsection{Stopy po technice vytahování}

Povrchové stopy jsou většinou odstraněny použitím sekundárních technik. Občas se objevuje série vertikálních žlábků po tahu prstů. V tlouštce stěny jsou patrné pravidelné vertikální rozdíly původních tahů prsty, které mohou být znatelné v horizontální rovině stěny (Rye 1981, 72).

\subsection{Stopy po technikách tvarování ná- dob z válečků}

\subsubsection{Stopy po stáčení válečků}

U této techniky je opět možné rozlišit dvě formy dna. První je vytvořeno z válečků jejich spojením a deformováním bez použití rotace. $\mathrm{Na}$ povrchu dna se objevují šroubovité rýhy, které vznikají špatným spojením dvou částí a také v důsledku dalších jevů jakými jsou smrštování jílo̊ nebo změna teplot. Druhé dno je malého kruhového průměru. Přidáváním válečků, které ho obklopují, dochází pak k formování těla nádoby. Na vnitřní straně nádoby může být viditelná linie, kde došlo k napojení dalších částí (Dupont-Delaleuf 2011, 43-45).

$\mathrm{Na}$ těle nádob je často viditelná přítomnost válečků zejména na vnitřním povrchu nádob, který nebývá tak pečlivě opracován. Obecně se u technik využívajících spojování válečků mohou se objevovat tenké rýhy, tzv. tlakové linie, které vznikají tlakem v místě spoje neúplně slepených válečků a to nejčastěji v průběhu sušení. Dalším jevem jsou tzv. vakuoly (obr. 11a). Termín pochází z biologie a je využíván také v mineralogii pro označení dutiny. V archeologickém kontextu 

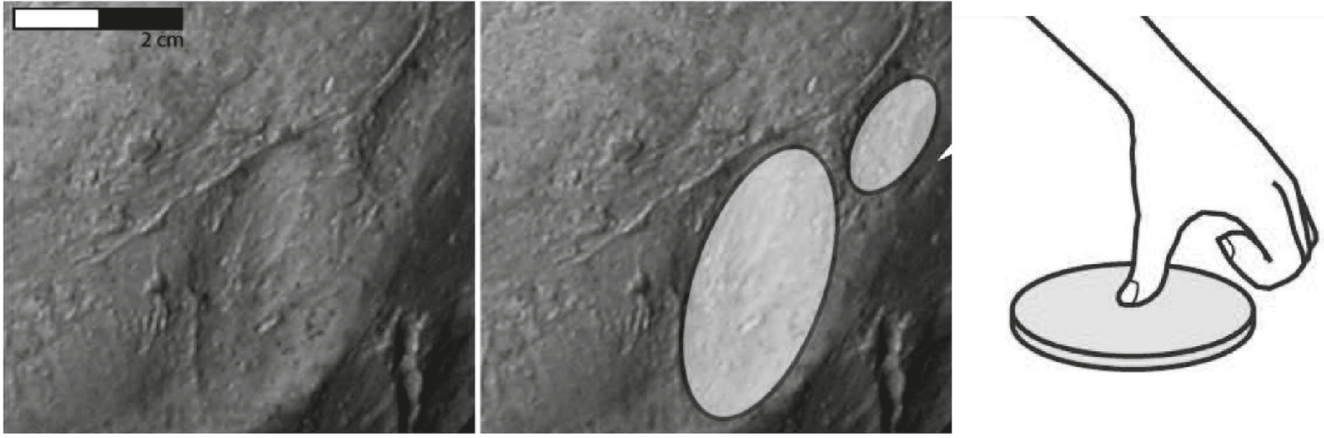

Obr. 8. Stopy po technice vymačkávání (podle Dupont-Delaleuf 2011).

Fig. 8. Traces of pinching technique (after Dupont-Delaleuf 2011).
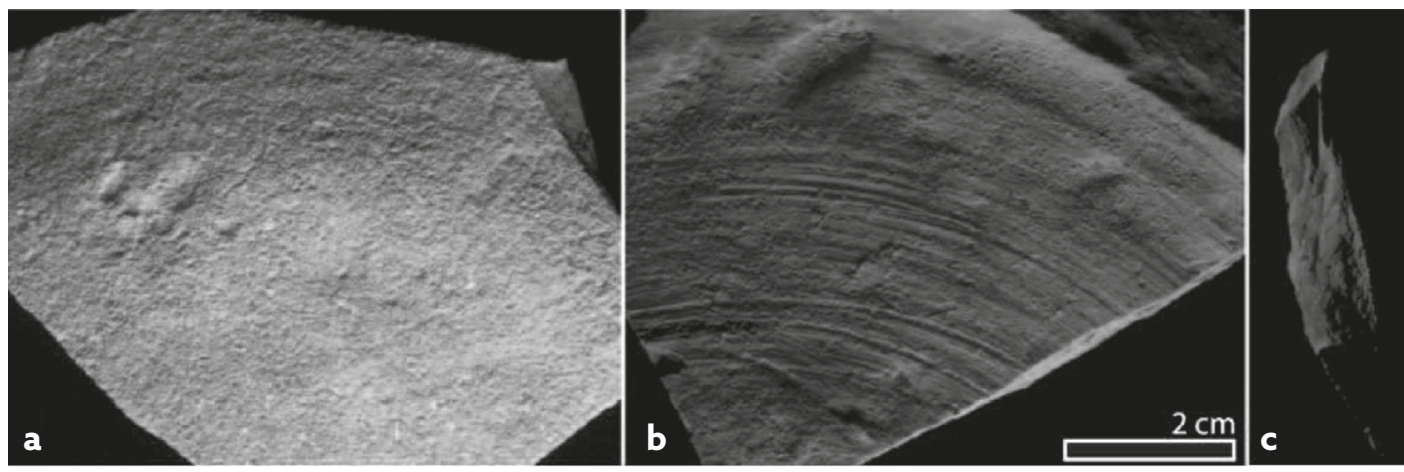

Obr. 9. Stopy po technice tvarování do formy (podle Dupont-Delaleuf 2011): a) povrch tvořený rukou nebo nástroji, b) povrch tvořený formou, c) profil fragmentu.

Fig. 9. Traces of mould pressing (after Dupont-Delaleuf 2011): a) surface shaped by hand or by tools, b) surface shaped by a mould, c) profile of a fragment.
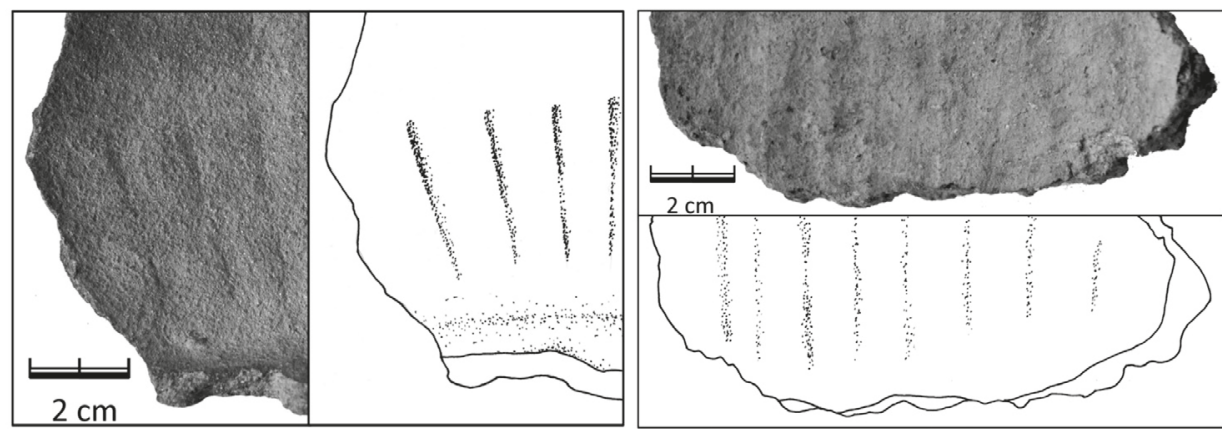

Obr. 10. Stopy v podobě vertikálních žlábků po technice vytahování (archiv autorky).

Fig. 10. Traces in the form of vertical grooves after lifting (archive of the author). 

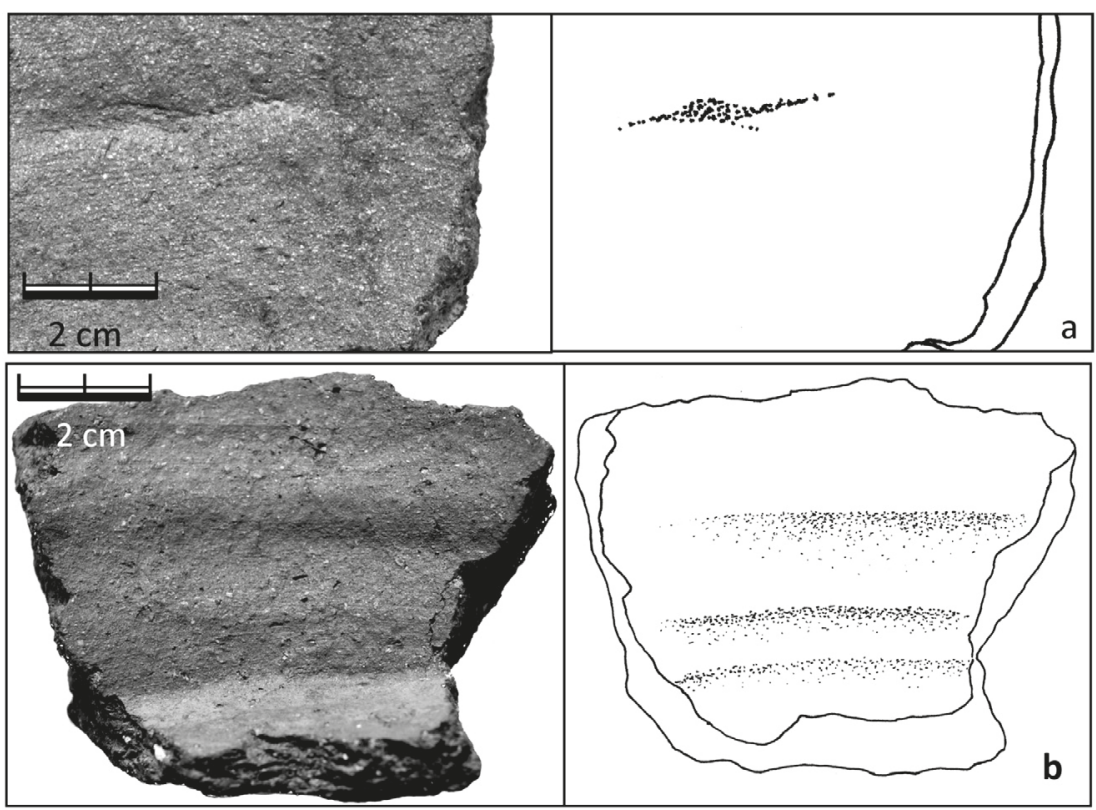

Obr. 11. Stopy po technice stáčení z válečků (archiv autorky): a) vakuoly, b) lineární deprese mezi válečky.

Fig. 11. Traces of the coiling technique (archive of the author): a) vacuoles, b) linear depressions between individual clay rolls.

jsou jako vakuoly označeny drobné dutinky, které vznikly neúplným „vyspárováním“ (rozhnětením válečků) stěny nádoby. Vakuoly jsou jasně ohraničené a zpravidla hluboké a vyznačují se cyklickým výskytem v určitých intervalech. Nejčastější formou povrchových stop jsou lineární deprese mezi jednotlivými válečky (obr. 11b). Deprese nemusí být vždy makroskopicky viditelné. Mohou být ale citlivé na dotek a projevovat se na lomu jako nerovnoměrnosti v síle stěny (Dupont-Delaleuf 2011, 48-50; Rye 1981, 67; Rzeznik 1995, 66).

$\mathrm{V}$ ideálních případech je u této techniky možné rozlišit, jakým způsobem byly na sebe válečky kladeny. První způsob umistuje válečky ve formě kroužků horizontálně na sebe, druhým způsobem jsou válečky kladeny na sebe ve spirále a jsou tedy orientovány šikmo ( $D u$ pont-Delaleuf 2011, 50-51). Teoreticky je rovněž možné určit, zda byly válečky kladeny paralel- ně na sebe nebo byl vrchní váleček umistován z vnější/vnitřní strany spodního válečku (Rzeznik 1995, 70).

\subsubsection{Stopy stáčení na kruhu}

Obecně se na těle takto vyrobených nádob objevují jemné horizontální žlábky, které vznikají působením prstů při rotaci nádoby, a zároveň známky stáčení jako např. vakuoly nebo stopy po spojení válečků (Dupont-Delaleuf 2011, 5254). V. Roux (1998, 752), která rozlišuje čtyři způsoby výroby nádob touto technikou, odlišuje také čtyři typy stop viditelných na povrchu. První způsob zanechává pravidelné stěny bez známek tažení hlíny (obr. 12a). Druhá metoda nepůsobí dostatečným tlakem a na nádobách jsou viditelné linie po válečcích (obr. 12b). Třetí způsob vytváří tlak na spoje válečků a tím vzni- 

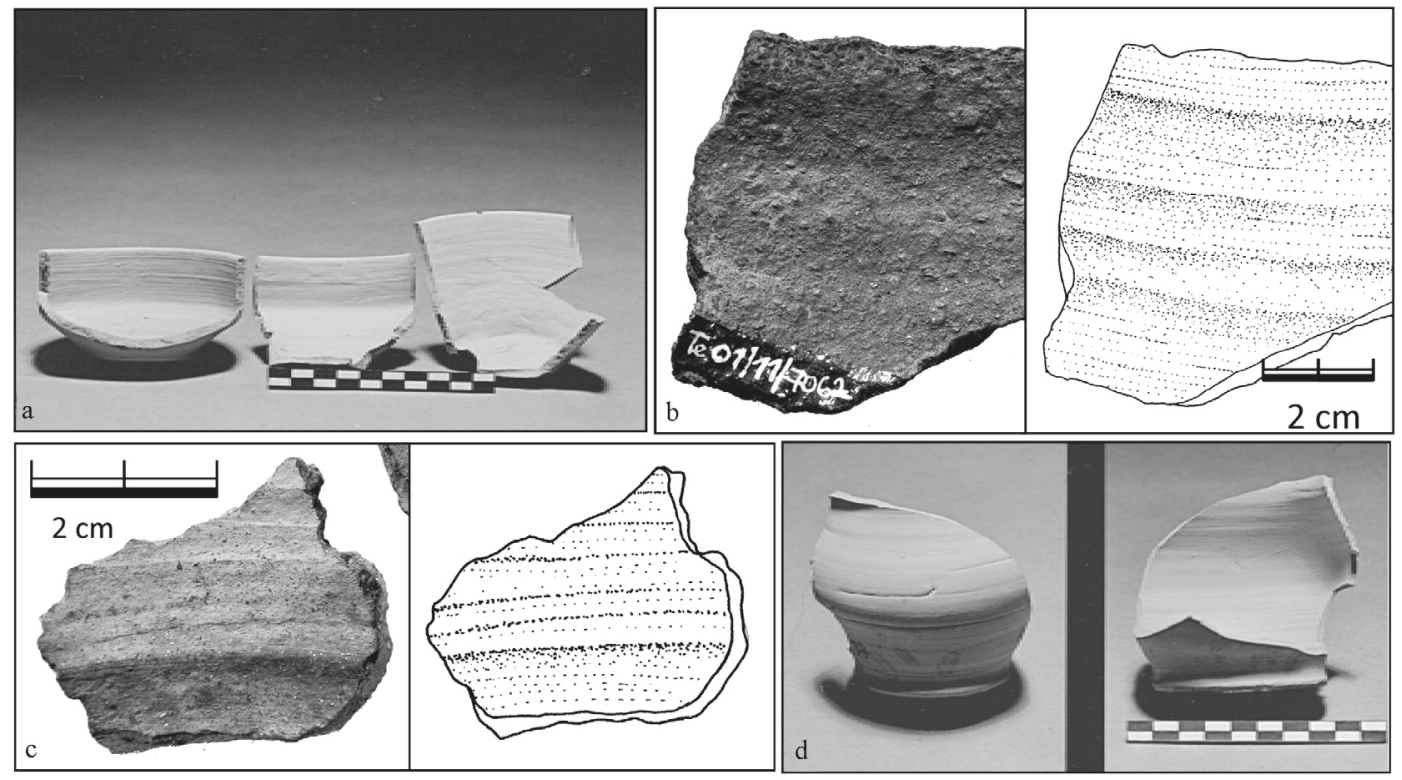

Obr. 12. Stopy po technikách stáčení na kruhu (podle Roux - Courty 1998; archiv autorky): a) pravidelné stěny spojené s metodou 1, b) linie po válečcích s jemnými paralelními rýžkami po metodě 2, c) variabilní př́ičné žlábky ukazujicí na metodu 3, d) jemné hřbety mezi spoji válečků u metody 4.

Fig. 12. Traces of wheel coiling techniques (after Roux - Courty 1998; archive of the author): a) even walls connected with method 1, b) lines after clay rolls with fine parallel grooves connected with method $2, c$ ) variable transverse grooves indicating the use of method $3, d$ ) fine ridges between joints of individual clay rolls in method 4 .

kají skupiny př́íčných žlábků (obr. 12c). Čtvrtý postup ukazuje paralelní žlábky v místě spojení válečků a jemné „hřbety“ mezi jednotlivými spoji (obr. 12d).

\subsection{Stopy po technice vytáčení}

Dna vytáčených nádob mají symetrický profil stěny a jejich plocha je rovná nebo konvexní. Na jeho povrchu nejsou viditelné žádné prohlubně, ale může být pokryt jemnými rýhami nebo být mírně zvlněný. Charakteristický je také tzv. pupek vytvářející se na středu vnější strany dna nahromaděním hlíny ve fázi otevírání. Pupek se nemusí objevovat na všech nádobách, lze jej odstranit při úpravě dna at už ve fázi primárního nebo sekundárního formování. Výroba dna probíhá současně s výrobou celé nádoby za pomoci rotace kruhu (Dupont-Delaleuf 2011, 46; Rye 1981, 75).

$\mathrm{Na}$ těle nádob vznikají ve fázi vytahování jemné spirálové žlábky. Dle sklonu žlábků, je možné určit, jakým směrem kruh rotoval - pokud jsou žlábky skloněné z leva doprava, kruh rotoval po směru hodinových ručiček. Tyto spirálové žlábky mohou být viditelné na vnitřní straně nádob, zejména u dna. Ve fázi tvarování se vytváří žlábky, které mají spíše horizontální orientaci a jsou mělké a nevýrazné. Zároveň může vznikat série jemných linií/rýžek působením bříšek hrnčíŕrových prstů. Často si lze povšimnout přítomnosti světlejších pruhů, které vznikají ředěním hlíny s vodou během vytáčení (Rye 1981, 75). Pokud se ve hmotě objevují hrubší příměsi, mohou zpơsobit také nerovnoměrnosti a nesymetričnost (Méry - Delaleuf Leeuw 2010, 54). 

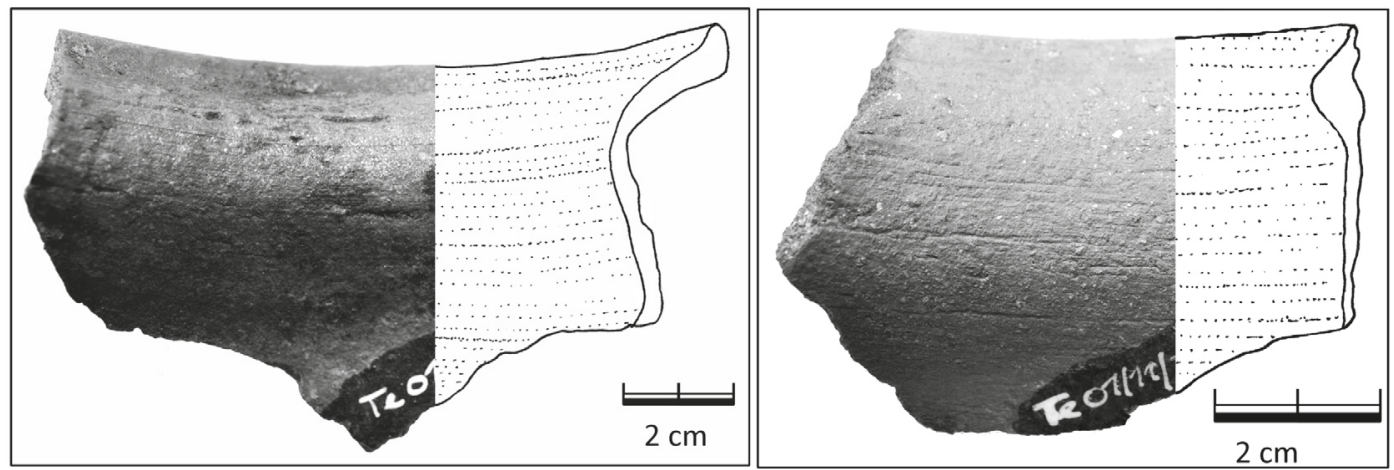

Obr. 13. Jemné spirálovité žlábky po technice vytáčení na kruhu (archiv autorky).

Fig. 13. Fine spiral grooves after wheel throwing (archive of the author)

\subsection{Další stopy spojené s výrobními technikami}

Během procesu vytáčení je nutné vyráběnou nádobu i ruce hrnčíře neustále namáčet vodou, aby hlína lépe klouzala a byla plastičtější. Přidaná voda zároveň stěnu oslabuje a mohou tak vznikat hluboké obloukovité pukliny, které se nejčastěji projevují na vnitřním dně nádoby. Na vnitřním povrchu stěn se pak vlivem sušení objevují praskliny spíše tenké a nepravidelné.

Dále je možné na vytáčených nádobách pozorovat šikmé zvlnění (zvrásnění), které lze označit jako komprimační záhyby. Vznikají během zužování průměru spodní části nádoby nebo hrdla. Tlak vyvíjený v takovém případě na nádobu je podobný škrcení a v případě, že je nádoba zúžena př́liš, objeví je právě toto zvrásnění (Dupont-Delaleuf 2011, 55; obr. 14a).

Další pozorovatelné stopy jsou spojeny s odřezáváním nádob od kruhu. Odříznutí se provádí pomocí šňůrky, drátu a v současnosti také pomocí vlasce/struny tahem těsně pod nádobou. Pokud je nádoba statická, odříznutí zanechá na spodní straně dna rovné paralelní rýhy (obr. 14b, 1). Pokud se nádoba při odřezávání pomalu otáčí, na dně zůstanou oblé linie (obr. 14b, 2). Při odřezávání rotující nádoby vzniká na dně tzv. lasturovitý vzor (obr. 14b, 3). Nádoby mohou být ke kruhu připevněny také pomocí kousků hlíny, které se rozhnětou částečně na nádobu a částečně na kruh. Takové nádoby je pak možné odříznout kolmými pohyby směrem ke kruhu nebo otočné podložce, kterou hrnčír pomalu otáčí. Odříznuta je rozhnětená hlína, která drží nádobu na kruhu a může být odříznuta také část stěny nádoby. Horizontální rýžky na vnějším povrchu nádoby těsně u dna pak dokládají oříznutí nádoby pomocí nože a otáček kruhu nebo otočné podložky (Rzeznik 1995, 76, obr. 14c). Dalším užívaným způsobuje odřezávání dna nádob pomocí nože, které zanechává hlubší zářezy na spodním okraji den (Fusek 2009, 99; obr. 14d).

\section{Praktický exkurz}

Podrobnější studium výrobních technik proběhlo na keramickém souboru ze sídliště objeveného na dně Staroměstského rybníka v Telči. Sídliště je datováno do 2. poloviny 12. století se zánikem v 2. polovině 14 . století, jež souvisel s vybudováním rybníka jako součásti fortifikační soustavy nově vznikajícího města Telče (Zimola 2012; Bláha 1982, 336). 

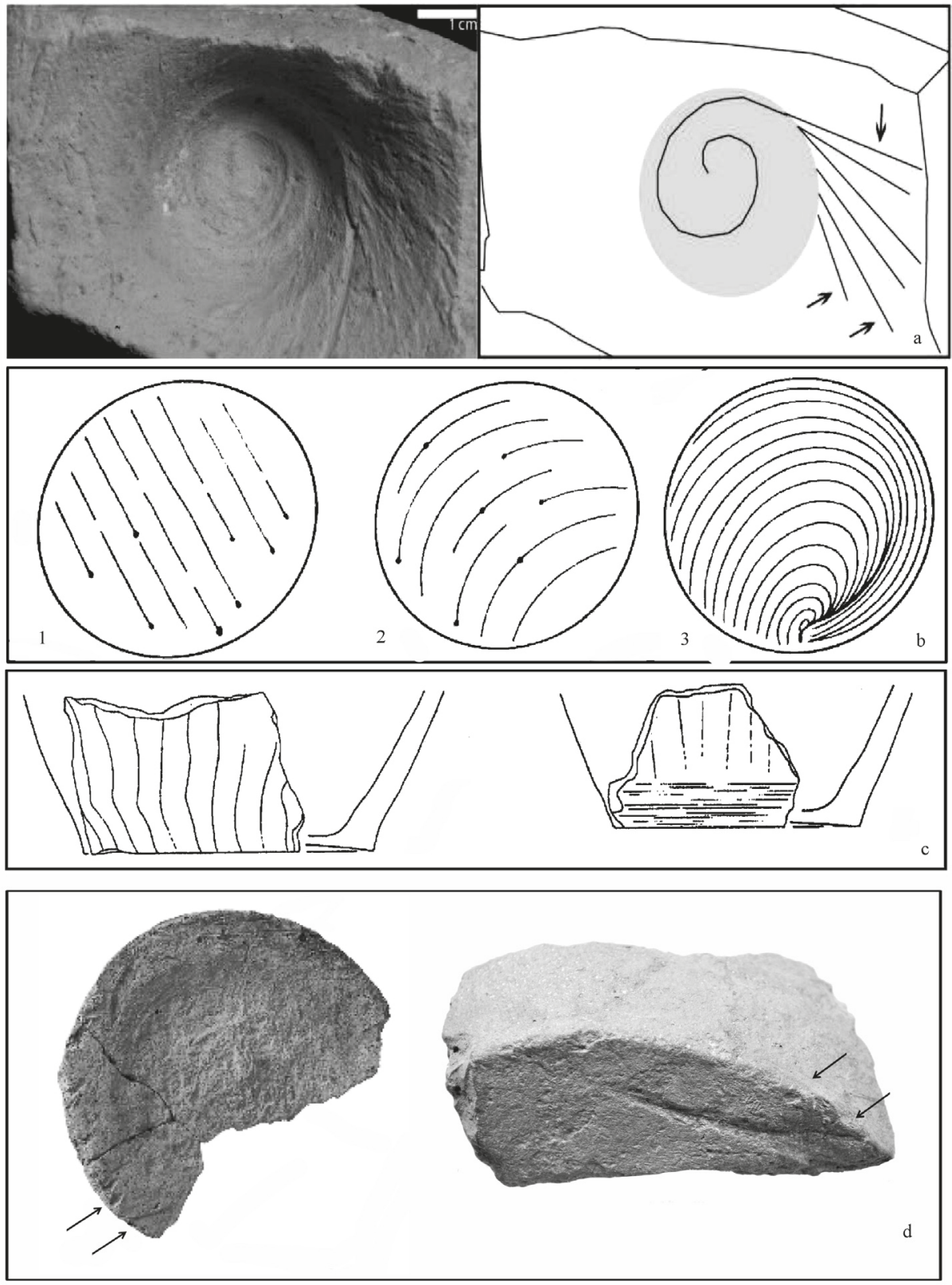

Obr. 14. Další stopy spojené s výrobními technikami (podle Dupont-Delaleuf 2011; Rye 1981, Rzeznik 1995; Fusek 2009; archiv autorky): a) šikmé zvlnění vzniklé při zužování průměru nádoby, b) stopy na dně po odřezávání nádoby od kruhu, c) stopy na povrchu po odřezávání z kruhu, d) zářezy na dně nádob po odřezávání nožem.

Fig. 14. Another traces connected with production techniques (after Dupont-Delaleuf 2011, Rye 1981; Rzeznik 1995; Fusek 2009; archive of the author): a) oblique undulation caused by narrowing the diameter of the vessel, b) traces at the bottom caused by cutting the vessel loose from the potter's wheel, c) traces on the surface caused by cutting the vessel loose from the potter's wheel, $d$ ) incisions at the bottom caused by cutting the vessel loose by a knife. 
Telčská keramika vykazuje charakteristické znaky pro toto období a oblast. Mimo tuhovou keramiku s jednoduššími variantami okrajů, kterou lze řadit do starší fáze fungování sídliště, se zde vyskytuje také vyspělejší keramika $\mathrm{s}$ širším tvarovým a morfologickým spektrem. Projevy tzv. kolonizační keramiky (nové tvary nádob, nová technologie výroby keramiky vytáčením) se zde mísí s domácími tradičními prvky. Doloženy jsou nádoby vyrobené z tradiční mladohradištní tuhové hmoty vytáčením na kruhu do tvarů džbánů a pokliček a zároveň se zde objevují nádoby vyráběné jednoduššími technikami s využitím nové písčité hmoty. Velkým podílem jsou v soboru zastoupeny také masivní tuhové zásobnice, jejichž technologie se na telečském sídlišti v čase příliš neměnila. Výsledky analýzy taktéž ukazují, že i v poměrně homogenním souboru je možné identifikovat mnohem širší škálu užitých technik. Převážná část studovaných nádob byla vyrobena bud' vytáčením na kruhu, nebo technikou stáčení na

\section{Literatura}

Arnold, D. 1999: Advantages and Disadvantages of Vertical-Half Molding Technology: Implications for Production Ogranization. In: Skibo, M. J. Feinman, M. G.: Pottery and People: A Dynamic Interaction. Salt Lake City, 59-80.

Arnold, D. - Nieves, A. L. 1992: Factors Affecting Ceramic Standardization. In: Bey, J. G. - Pool, Ch.

A.: Ceramic Production and Distribution: An integrated Approach. Boulder, 93-113.

Bareš, M. - Lička, M. - Růžičková, M. 1981: K technologii výroby neolitické keramiky I, Sborník Národního muzea v Praze, řada A-historie, roč. 35, 137-226.

Bareš, M. - Lička, M. - Růžičková, M. 1982: K technologii výroby neolitické keramiky II, Sborník Národního muzea v Praze, řada A-historie, roč. 36, 121-237. kruhu. V menší míře se pak objevují techniky stáčení válečků, vytahování a také stopy úprav povrchu ostrým nástrojem, které jsou patrné zejména na vnitřní straně zásobnic.

\section{Závěr}

Podrobnější studium technologie výroby keramických nádob sebou nese značné problémy, jako je zatížení stereotypy při studiu, neucelenou nomenklaturu a v neposlední řadě také obtížnost jednoznačného rozpoznání použitých technik. Přesto jsou techniky výroby nedílnou součástí procesu, bez něhož by dané nádoby nevznikly a měla by jim proto být věnována pozornost. Tento příspěvek si kladl za cíl především seznámit badatele s různými technikami výroby nádob, které mohly být $\mathrm{v}$ minulosti využívány a také se stopami, které po sobě mohou zanechávat. Pro další studium je nutné vytvořit systematiku znaků, které povedou k přesnějšímu určení technologie.

Bernhardt, T. 2011: Experimentální ověření možnosti výroby podsýpané keramiky na rychle rotujícím kruhu. In: Orna, J. a kol.: Keramická produkce města Plzně v období 14. a 15. století. Plzeň, 67-75.

Bláha, J. 1982: Výsledky průzkumů zaniklých středověkých sídlišt v horním Podyjí, Vlastivědný věstník moravský XXXIV, Brno, 334-342.

Bočková, Z. - Doležalová, K. - Kochan, Š. - Mazáčková, J. - Slaviček, K. - Těsnohlídek, J. 2014: Experimentální výroba keramiky v Panské Lhotě, Archaeologia historica 39, 119-137.

Buko, A. 1990: Ceramika wczesnopolska: Wprowadzenie do badan. Wroclaw.

Courty, M. A. - Roux, V. 1995: Identification of Wheel Throwing on the basis of Ceramic Surface Features and Microfabrics, Journal of Archaeological Science 22, 17-50.

Černohorský, K. 1952: Keramika a feudalismus, Český lid 39, 223-230. 
Dolors, R. 2003: Keramika. Praha.

Dupont-Delaleuf, A. 2011: Styles techniques des céramiques de la protohistoire en Asie centrale : méthodologie et études de cas, Thèse de doctorat, Université Paris Ouest-La Défense (inédit).

Dvorská, J. 2001: Experimentales Brennen von Keramik - eine naturwissenschaftliche Studie, Archeologické rozhledy LIII, 45-58.

Feinman, G. M. - Kowalewski, S. A. - Blanton, R. E. 1984: Modeling ceramic production and organizational change in the Pre-hispanic Valley of Oaxaca, Mexico. In. Leeuw, S. E., van der - Pritchard A. C. (ed.): The many dimensions of pottery: ceramics in archaeology and antropology. Amsterdam, 295-337.

Fusek, G. 2009: Otlačky na dnách nádob v Nitre-Šindolke, Archeologie doby hradištní v České a Slovenské republice, Supplementum 2, 99-108.

Gregerová, M. a kol. 2010: Petroarcheologie keramiky v historické minulosti Moravy a Slezska. Brno.

Gruner, D. 1988: Unterschiedliche Wulsttechniken in Nord- und Westafrika. In: Lüdtke, H. Vossen, R. (ed.): Töpferei und Keramikforschung, Bd. 1. Bonn, 73-80.

Hanykýr, V. a kol. 2011: Keramika. Plzeň.

Hofer, N. (ed.) 2010: Handbuch zur Terminologie der mittelalterlichen und neuzeitlichen Keramik in Österrech. Wien.

Holmes, W. H. 1901: Use of Textiles in Pottery Making and Embellishment, American Anthropologist, New Series, Vol. 3., No. 3, 397-403.

Holubowicz, W. 1965: Gancarstvo wcesnosredoniowieczne Slowian. Wroclaw.

Chavarria, J. 1999: Velká kniha keramiky. Praha.

Kovárnik, J. 1982: K výrobní technologii neolitické keramiky, Sborník prací Filozofické fakulty Brněnské univerzity $\mathrm{E} 27,103-116$.

Kovárnik, J. 1983-84: Zur Technologie der neolithischen Keramik, Mitteilungen der österreichischen Arbeitsgemeinschaft für Ur- und Frühgeschichte 33-34, 151-169.

Kovárnik, J. 2005: Výroba keramiky. In. V. Podborský (ed.), Pravěk mikroregionu potoka Těšetičky/ Únanovky. Brno, 124-127.

Livingstone Smith, A. 2010: Reconstitution de la chaîne opératoire de la poterie, Bilan et perspectives en Afrique sub-saharienne, Les Nouvelles de l'archéologie 119, 9-12.
Livingstone Smith, A. - Van Der Veken, A. 2009: Crossing Borders Project: Potetry traditions in Katanga (DCR), Afrique: Archéologie \& Arts 5, 141-148.

Ludikovský, K. 1960: K technologii na kruhu vyráběné pravěké keramiky, Archeologické rozhledy XII, 66-79.

Macháček, J. 2001: Studie k velkomoravské keramice. Metody, analýzy a syntézy, modely. Brno.

Méry, S. - Delaleuf, A. - Leeuw, S. 2010: Analyse technologique et expérimentations, Les techniques de façonnage céramique mettant en jeu la station à Hili (Émirats arabes unis) à la fin du IIIe millénaire (âge du Bronze ancien). In: Giligny, F. et Méry, S. (éds.), Les Nouvelles de l'Archéologie 119. Paris, 52-58.

Nekuda, V. - Reichertová, K. 1968: Středověká keramika v Čechách a na Moravě. Brno.

Neumannová, K. 2013: Technologie keramiky a chaînes opératoires, příspěvek na 4. keramickém workshopu v Panské Lhotě ve dnech 12. - 15. 8. 2013.

Pavli̊, I. 1971: Pražská keramika dvanáctého a třináctého století. Praha.

Podborský V. (ed.) 2005: Pravěk mikroregionu potoka Těšetičky/Únanovky. K problematice pravěkých sociálních struktur. Brno.

Polla, B. 1962: Stredoveká zaniknutá osada na Spiši (Zalužany). Bratislava.

Procházka, R. 2007: Deskripční systém brněnské keramiky, Příloha 1, Přehled výzkumů 48, 234-270.

Rada, P. 1997: Slabikář keramika. Praha.

Reichertová, K. 1965: Středověká keramika ze Sezimova Ústí, Tábora a Kozího hrádku. Příspěvek ku chronologii a tvarosloví středověké keramiky. Praha.

Rice, P. M. 1981: Evolution of specialized pottery production: a trian model, Current Anthropology, vol. 22, no. 3, 219-240.

Roux, V. 2009: Wheel Fashioned Ceramic Production during the Thiird Millennium BCE in the Southern Levant: a Perspective from Tel Yarmuth. In: Rosen S. A. - Roux, V. (ed.), Techniques and People, Anthropological Perspectives on Technology in the Archaeology of the Proto-historic and Early Historic Periods in the Southern Levant. Paris, 195-212.

Roux, V. - Corbetta, D. 1989: The Potter's Wheel: Craft Specialization and Technical Competence. New Delhi-Bombay-Calcutta. 
Roux, V. - Courty, M. A. 1998: Identification of Wheel-fashioning Methods: Technological Analysis of 4th-3rd Millennium BC Oriental Ceramics, Journal of Archaeological Science 25, 747-763.

Rye, O. S. 1981: Pottery technology. Principles and reconstruction. Wahington.

Rzeznik, P. 1993: Przyczynek do studiow nad technika wykonania naczyn wczesnosredniowiecznych, Przeglad Archeologiczny, vol. 41, 75-86.

Rzeznik, P. 1995: Frühmittelalterliche Töpfertechniken im Lichte der Keramik von der Dominsel zu Wroclaw. In: Poláček, L. (Hrsg.), Slawische Keramik in Mitteleuropa vom 8. bis zum 11. Jahrhundert. Terminologie und Beschreibung. Brno, 65-78.

Shepard A. O. 1956: Ceramics for the archaeologist. Washington D.C.

Schneider, K. 1991: Töpferei der Lobi. In: Lüdtke, H. - Vossen, R. (ed.), Töpferei - und Keramikforschung, Bd. 2. Bonn, 65-91.

Stark, M. T. 1991: Ceramic production and comunity specialization: a Kalinga ethnoarchaeological study, World Archaeology, Vol. 23, No. 1, 64-78.

Štajnochr, V. 1998: Archaické technologie tváření keramiky, Archeologické rozhledy L, 95-105.

Thér, R. 2004: Experimental pottery firing in closed firing devices from the Neolithic - Hallstatt Period in Central Europe. EuroREA 1, 35-82.

Thér, R. 2009: Technologie výpalu keramiky a její vztah $\mathrm{k}$ organizaci a specializaci ve výrobě keramiky v kontextu kultur popelnicových polí, nepublikovaná disertační práce na Ústavu antropologie Přírodovědecké fakulty Masarykovy univerzity. Brno.
Thér, R. - Gregor, M. 2011: Experimental reconstruction of the pottery firingprocess of late bronze age pottery from nort-eastern Bohemia. In: Scarcella, S. (ed.): Archaeological Ceramics: A Review of Current Research. Oxford, 128-142.

Thér, R. - Mangel, T. 2014: Inovace a specializace $\mathrm{v}$ hrnčířském řemesle $\mathrm{v}$ době laténské: model vývoje forem organizace výroby, Archeologické rozhledy LXVI, 3-39.

Tichý, R. - Tintěra, L. 2001: Výpal keramiky v jámě (zahloubeném ohništi), Rekonstrukce a experiment $\mathrm{v}$ archeologii 2, 114-120.

Tintěra, L. - Červinková, H. - Červinka, J. 1986: Experimentální ověření výrobních možností miliřrovitých hrnčirřských pecí, Archaeologica Pragensia, 273-292.

Vařeka, P. 1998: Proměny keramické produkce vrcholného a pozdního středověku v Čechách, Archeologické rozhledy L, 123-137.

Virot, C. 2005: La poterie africaine: les techniques céramiques en Afrique noire. Banon.

Vuković, J. 2014: Archaeological Evidence of Pottery Forming Sequence: Traces of Manufacture in Late Neolithic Vinča Assemblage. In: Vitezović, S. - Antonović, D. (ed.): Archaeotechnology: studying technology from prehistory to the Middle Ages. Beograd, 177-198.

Zápotocký, M. 1979: Katalog středověké keramiky severočeského Polabí. Praha.

Zimola, D. 2012: Zpráva o archeologické akci, Identifikace akce: „Rekonstrukce a odbahnění rybníka Staroměstský v Telči“, uloženo v Muzeu Vysočiny Jihlava. 


\section{On the problem of production technology of ceramic vessels and its nomenclature}

Ceramic technology comprises a whole series of processes, from raw material extraction, over the production of vessels through to final firing. In Czech archaeology, the study of production technologies of historical pottery remains neglected. More detailed works are only focused on firing technology (e.g. Thér 2009; Kovárnik 1982; Dvorská 2001; Bareš - Lička - Růzičková 1981, 1982). The study of production techniques of individual vessels is often limited to mere distinction between three techniques (coiling, turning, wheel throwing). Production technology of vessels, however, should be an important criterion in evaluation of pottery because it informs us not only about the technologies themselves, but also about socio-economical aspects of historical populations. The objective of the paper is to make the researchers familiar with techniques which may have been used in the past for production of vessels, as well as with specific traces which they leave on final products. Another goal is to draw the attention to a unified nomenclature and the problems with usage of several terms.

The process of vessel production can be divided into two basic phases - primary forming, where a lump of clay is being formed until it reaches the intended shape of a vessel (the result is a roughout), and secondary forming, where the final dimensions of the product are defined (the result is a preform). Among primary techniques are, for example: pinching (Fig. 1), slab building (Fig. 2), mould pressing (Fig. 3), slip casting, lifting (Fig. 4), coiling (Fig. 5), wheel coiling (Fig. 6), wheel throwing (Fig. 7). Secondary techniques comprise scraping, trimming, turning etc. The third phase is represented by surface finish which is made with the help of smoothing, burnishing, relief appliqués, etc.

Each of the above-mentioned techniques leaves specific traces on the surface of the product. On the basis of these special marks we can determine the production procedure of each vessel. Macroscopic determination of production techniques, however, can be complicated by poor visibility of individual traces, considerable fragmentation of pottery, state of preservation (the differences in techniques are often well visible on the fracture). It is also true that not all historical periods are suitable for this study. It is highly recommended to supplement the macroscopic study with natural scientific analyses and experiments.

The pinching technique manifests itself by shallow finger imprints (Fig. 8). Mould pressing is typically indicated by transverse grooves resulting from the contact between clay and the material of the mould or an anti-adhesive material (mostly ash or sand; Fig. 9). Lifting technique leaves vertical furrows made by fingers on the inside of the vessel (Fig. 10). Coiling is characterised by linear depressions between individual clay rolls, especially on the inner surface of the vessel (Fig. 11). The technique of wheel coiling leaves traces of individual clay rolls in combination with fine grooves resulting from the rotational trimming of vessels (Fig. 12). Wheel-thrown vessels made from a single ball of clay are characterised by even walls, symmetrical profile and fine spiral grooves made by potter's fingers (Fig. 13). Narrowing of the vessel's shape during wheel throwing can result in oblique undulation caused by strangling-like pressure (Fig. 14a). Another observable traces emerged when vessels were cut loose from the potter's wheel by pulling a string immediately under the vessel (Fig. 14b) or by applying moves perpendicular to the wheel (Fig. 14c).

A problem with study of pottery technology can arise with translation of specialised terms from/into foreign languages (Tab. 1). Another problems are connected with traditional assumptions in determination of production techniques. An example thereof can be the claim that the vessels whose bottoms bear traces of anti-adhesive material sprinkled over the potter's wheel can only be made with a slowly rotating hand-operated tournette. However, experiments proved that vessels with such bottoms can also be made with a fast-rotating wheel, regardless of the complexity and non-probability of using this method. Another obstacle is represented by the non-uniform terminology with ambiguous use of several terms 
(e.g. hand-building - coiling - wheel coiling; turning as trimming of vessels made from clay rolls - as shaping of vessels on a wheel with the help of a mould), especially in cooperation with other disciplines. For example, the so-called coiling technique is sometimes also referred to as hand-building or turning. In several other cases, this term is used with vessels made statically by adding individual clay rolls to the vessel's body where one coil is placed on top of another (often in prehistoric pottery). This technique is usually connected with production of vessels without rotation or with the help of a slowly rotating tour- nette (approximately since the early historic period). Particularly the term wheel coiling suggests in this regard that the vessel was made from clay rolls and its shape was subsequently modified with the help of a rotating wheel. In present-day pottery making, however, turning means the modification of surface qualities of a morphologically finished product, most frequently the so-called leather-hard ware (i.e. at a time when the vessels are already partially dried), with the help of tools. Herewith it is a secondary production technique.

\section{Lenka Běhounková}

- Ústav archeologie a muzeologie,

Filozofická fakulta, Masarykova univerzita,

A. Nováka 1, 60200 Brno, Česká republika

behounkovalenka@gmail.com 